\title{
Biological and chemical factors controlling the patchy distribution of soil water repellency among plant species in a Mediterranean semiarid forest
}

\author{
E. Lozano a, , P. Jiménez-Pinilla a , J. Mataix-Solera ${ }^{a}$, V. Arcenegui ${ }^{a}$, G.M. Bárcenas ${ }^{\text {b }}$, J.A. González-Pérez ${ }^{c}$, \\ F. García-Orenes ${ }^{a}$, M.P. Torres ${ }^{\mathrm{d}}$, J. Mataix-Beneyto ${ }^{\mathrm{a}}$

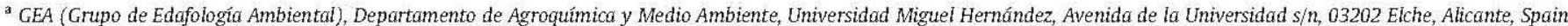 \\ 'MED_Soil Research Group, Departamento de Cristalografia, Mineralogía y Química Agricola, Facuitad de Química, Universidad de Sevilia, C/Profesor García González, 1 , \\ 41012 Sevilla, Spain \\ ${ }^{c}$ Instituto de Recursos Naturales y Agrobiología de Sevilla, IRNAS-CSIC, Av. Reina Mercedes, 10, 4012 Sevilla, Spain \\ 'Área de Botánica, Departamento de Biología Aplicada, Universidad Miguel Hernández, Avenida de la Universidad s/n, 03202 Elche, Alicante, Spain
}

\begin{abstract}
Natural soil water repellency is a property that has already been observed in forest soils and is characterized by its patchy distribution. There are many factors involved in its development. In this work, we have studied a large number of chemical and biological factors under the influence of different plant species (Pinus halepensis, Quercus rotundifolia, Cistus albidus and Rosmarinus officinalis) to learn which has the greatest responsibility for its presence and persistence in the top-soil layer. We observed strong and significant correlations between ergosterol, glomalin related soil protein (GRSP), extractable lipids, soil organic matter (SOM) content and water repellency (WR). Our results suggested lipid fraction as the principal factor. Moreover, apart from Pinus, fungal biomass seems to be also related to the SOM content. Soil WR found under Pinus appears to be the most influenced by fungi. Quality of SOM, to be precise, lipid fraction could be responsible for WR and its relationship with fungal activity.
\end{abstract}

\section{Introduction}

Soil water repellency (WR) has been observed in forest soils under different climatic conditions, soil types and vegetation covers (Doerr et al., 2000). Soil WR is normally characterized by a high spatial variability in persistence, with wettable and water repellent patches next to each other. This phenomenon is of special interest in semiarid areas, such as Mediterranean ecosystems, where water is considered to be one of the fundamental controls affecting the structure, function, and diversity of ecosystems (Rodriguez-Iturbe, 2000). In ecosystems where water resources are limited, even slight WR may play an important role in the infiltration patterns and the spatial distribution of water in the soil (Mataix-Solera et al., 2007). WR has hydrological impacts, but also ecological consequences, with repercussions on plant growth (Doerr et al., 2000). This could be the reason why several studies single out the production of hydrophobins by plants, as a possible ecological strategy (Mataix-Solera et al, 2007). It is thought to be a mechanism for improving water conservation by channeling water deep into the soil profile following preferential flow pathways (Moore and Blackwell, 1998; Robinson et al., 2010), while at the same time reducing evaporation due to the spatial dryness of the surface layer (Doerr et al., 2000).
It has been proposed that the origin of natural WR is caused by organic compounds released from different plant species and sources, due to resins, waxes and other organic substances in their tissues. In the Mediterranean areas different evergreen trees (such as Pinus and Quercus) and shrubs are usually associated with soil WR under natural conditions (Arcenegui et al., 2008; Jordán et al., 2008; Mataix-Solera et al, 2007; Verheijen and Cammeraat, 2007). There is a large quantity of research publications that associate soil WR with the SOM content (Doerr et al., 2000; Mataix-Solera and Doerr, 2004; Zavala et al., 2009). Despite this, many of them suggest that this relationship could be due to the quality of SOM (Mataix-Solera et al., 2007; Rumpel et al., 2004). In fact, literature has emphasized the importance of lipid fractions released to soil by plants or microorganisms (fungi) (Franco et al., 2000; Hudson et al., 1994; Ma'shum et al., 1988), as well as the behavior of specific characteristics of the organic matter, in general associated with moisture regimes, e.g., temporarily waterlogged soils (Fridland, 1982). In particular, considerable experimental effort has been carried out in the last decade to identify specific substances with a potential relevance on WR (De Blas et al., 2010; Doerr et al., 2005b; Franco et al., 1994, 1995; Hudson et al., 1994; McIntosh and Home, 1994; Wallis et al., 1993).

On the other hand, research highlights the point that the relationship between WR and plants may not always be direct: a group of fungi and microorganisms, which might be associated with specific plants, could also contribute to soil hydrophobicity through their 
products or by processing organic material (Feeney et al., 2004; Hallett and Young, 1999; Morales et al., 2010; White et al., 2000). In concrete, fungal hyphae, glomalin related soil protein and more recently ergosterol are being studied to understand their influence on the development of soil WR (Rillig, 2005; Rillig et al., 2010; Young et al., 2012). GRSP is a glycoprotein produced primarily by arbuscular mycorrhizae (AM) (Buyer et al., 2011; Treseder and Turner, 2007). Glomalin is not exuded by AM hyphae, but is instead contained within hyphal walls (Driver et al., 2005). When the AM hyphae die and decompose, they are thought to leave a residue of glomalin in the soil (Treseder and Allen, 2000). The importance of the presence of GRSP relates to its supposed hydrophobic properties. Results on the influence of GRSP differ, so that the question is still unclear (Feeney et al., 2004; Young et al., 2012). Ergosterol is a specific component of fungal membranes and the major sterol in most filamentous fungi (Van den Bossche, 1990). It is recognized as being an important biomolecule through which reduced permeability may occur in a wide variety of biological surfaces/membranes (Young et al., 2012). Its content is considered as a marker for living fungi and a good estimate of metabolically active fungal mycelium in soil (Montgomery et al., 2000).

In this research we have studied at the same time chemical and biological factors involved in the occurrence of superficial soil WR under different plant cover. Our aim here is to find out about which factors are the most relevant in the development of soil WR and possible relationships between them. This research could be a contribution to better understanding of why this phenomenon occurs in the semi-arid Mediterranean context under natural conditions.

\section{Materials and methods}

\subsection{Study area}

The study area is located in the 'Sierra de la Taja' $\left(38^{\circ} 23^{\prime} \mathrm{N} ; 0^{\circ} 59^{\prime} \mathrm{W}\right)$ near Pinoso, in the province of Alicante (SE of Spain). The region has a semi-arid Mediterranean climate with a mean annual precipitation of $277.5 \mathrm{~mm}$ and a mean annual temperature of $15.8^{\circ} \mathrm{C}$ ranging from $7.8{ }^{\circ} \mathrm{C}$ in January to $24.1{ }^{\circ} \mathrm{C}$ in August (average $1980-2010$ ). The whole area of the 'Sierra de la Taja' is approximately 500 ha. The samples were taken under similar conditions with respect to soil type, geology, plant distribution and slope. The soil is a Lithic Xerorthent (Soil Survey Staff, 1998), developed over Jurassic limestone. The soil texture in the area is loam, with a $36 \%$ of sand, a $49 \%$ of silt and a $15 \%$ of clay.

The tree stratus of the area is formed by Pinus halepensis Miller of approximately 40 years and Quercus rotundifolia is also present. Shrub vegetation comprises mainly Quercus coccifera L., Rosmarinus officinalis L., Juniperus oxycedrus L., Cistus albidus L., Brachypodium retusum Pers. (Beauv.), Stipa tenacissima L., and Pistacia lentiscus L. Tree and shrub species are mixed in the study area, but as a consequence of the relatively low density of vegetation, it was possible to carry out the sampling in microsites per stem of each species, avoiding interference between them.

\subsection{Soil sampling}

Samples were taken in September 2011, when the soil WR is expected to be at its strongest after the typical Mediterranean summer drought (DeBano, 1981; Dekker and Ritsema, 1994; Doerr et al., 2000). Soil samples were collected from the first $2.5 \mathrm{~cm}$ of the mineral A horizon at microsites beneath each of the four most representative species (P. halepensis, $R$. officinalis, $Q$. rotundifolia and C. albidus; $\mathrm{n}=15$ per species) and 5 samples from bare soil with no influence from any species. The sampling was done by selecting stems randomly, and taking two samples per stem. Half of the samples were preserved and frozen at $-5{ }^{\circ} \mathrm{C}$ and the other half were preserved at $25^{\circ} \mathrm{C}$. The distance between the stems sampled was around $10 \mathrm{~m}$.

\subsection{Laboratory methods}

Soil samples (not frozen) were dried at room temperature (20$25^{\circ} \mathrm{C}$ ) to a constant weight and sieved $(2 \mathrm{~mm}$ ) to eliminate coarse soil particles before soil analysis. Soil pH was measured in aqueous soil extract in de-ionized water (1:2.5 w:s) at $25^{\circ} \mathrm{C}$. SOM content was analyzed by rapid dichromate oxidation of organic carbon (Walkley and Black, 1934).

For measuring WR, approximately $15 \mathrm{~g}$ of soil per sample was placed on separate $50-\mathrm{mm}$ diameter plastic dishes and exposed to a controlled laboratory atmosphere $\left(20{ }^{\circ} \mathrm{C}, \sim 50 \%\right.$ relative humidity) for one week to eliminate potential effects of any variations in preceding atmospheric humidity on soil WR and in accordance with the findings of Doerr et al. (2005a). The persistence of WR was measured by the Water Drop Penetration Time (WDPT) test (Wessel, 1988). This involved placing 3 drops of distilled water $(\sim 0.05 \mathrm{ml})$ onto the sample surface and recording the times required for their complete penetration. The average time for triplicate drops has been taken as the WDPT value of a sample. Penetration times were classified in intervals and in classes according to Bisdom et al. (1993), with WDPT $\leq 5 \mathrm{~s}$ representing wettable and WDPT $>5 \mathrm{~s}$ water repellent conditions. The logarithm of the WDPT value in seconds has been used; being water repellent if the value of $\log ($ WDPT) is $>0.7$. The water repellency classes used are indicated in Table 1.

Extractable lipids were Soxhlet-extracted from soil samples (10 g) with a dichloromethane-methanol $(3: 1 \mathrm{v} / \mathrm{v})$ for $16 \mathrm{~h}$ at $70{ }^{\circ} \mathrm{C}$ (González-Vila et al., 2003; Van Bergen et al., 1997). Extracts were filtered and dried and then total lipid content was gravimetrically determined and referred to as percentages of $g$ soil.

To determine the possible relationship of fungal activity and its presence in soil with WR, three different fungal parameters were measured; GRSP, mycelium length and ergosterol. GRSP measured was the Easily Extractable Glomalin, which corresponded with the fraction of protein most recently deposited into the soil. GRSP was extracted from $0.25 \mathrm{~g}$ subsamples with $2 \mathrm{ml}$ citric acid buffer, pH 7.0 at $121{ }^{\circ} \mathrm{C}$ for $30 \mathrm{~min}$. After extractions, samples were centrifuged at $3000 \times$ during $15 \mathrm{~min}$ to remove soil particles. Protein in the supernatant was determined by a Bradford assay (Wright and Upadhyaya, 1996). Concentrations of glomalin were extrapolated to $\mu \mathrm{g} / \mathrm{g}$ by correcting for the dry weight of coarse fragments ( $>0.25 \mathrm{~g}$ ) included in the extraction of soil.

For the measurement of mycelium length, hyphae were extracted from a $10 \mathrm{~g}$ soil subsample by an aqueous extraction and membrane filter technique (Bååth and Söderström, 1980; Bardgett, 1991; Hanssen et al., 1974). Soil samples were mixed and suspended in $100 \mathrm{ml}$ of deionized water. Suspensions diluted $\left(10^{-2} \mathrm{ml}\right)$ for measuring the mycelium length were stained with $0.05 \%$ Trypan Blue, and filtered

Table 1

WDPT classes and class increments used in the present study. After Bisdom et al. (1993).

\begin{tabular}{|c|c|c|c|c|c|c|c|c|c|c|}
\hline \multirow[t]{2}{*}{ Repellency rating } & \multirow[t]{2}{*}{ Wettable } & \multicolumn{9}{|c|}{ Water repellency } \\
\hline & & Slight & & & Strong & & & Severe & & Extreme \\
\hline WDPT classes & $\leq 5$ & 10 & 30 & 60 & 180 & 300 & 600 & 900 & 3600 & $>3600$ \\
\hline WDPT interval (s) & $\leq 5$ & $6-10$ & $11-30$ & $31-60$ & $61-180$ & $181-300$ & $301-600$ & $601-900$ & $901-3600$ & $>3600$ \\
\hline Log WDPT interval & $\leq 0.7$ & $0.7-1.0$ & $1.0-1.5$ & $1.5-1.8$ & $1.8-2.3$ & $2.3-2.5$ & $2.5-2.8$ & $2.8-3.0$ & $3.0-3.6$ & $>3.6$ \\
\hline
\end{tabular}




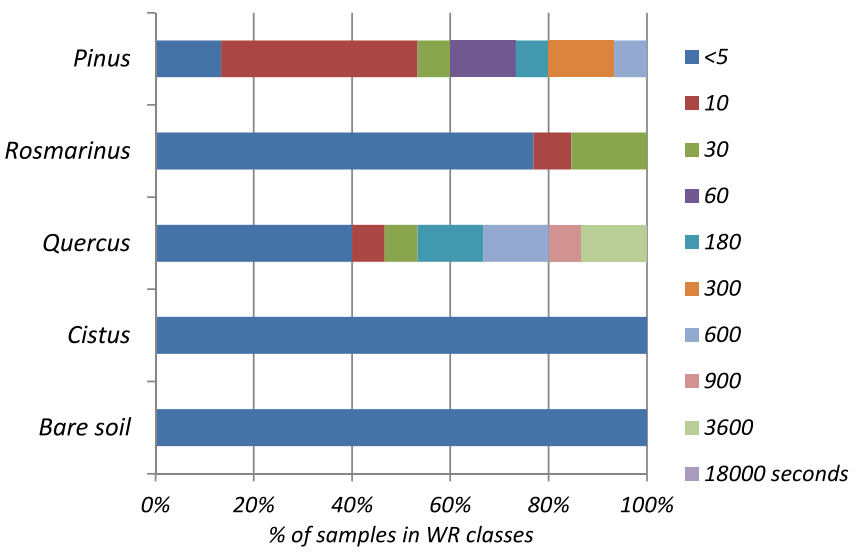

Fig. 1. Relative frequency of water repellency classes beneath the different species and bare soil $(\mathrm{n}=64)$.

(1.2 $\mu \mathrm{m}$ Millipore cellulose membranes) and transferred to microscope slides. The mycelium length was measured microscopically at $40 \times$.

Ergosterol extraction was done according to the method described by Rousk and Bååth (2007) to estimate metabolically active fungal mycelium. $1 \mathrm{~g}$ dry weight of soil was transferred to test-tubes and then ergosterol was extracted in $5 \mathrm{ml} \mathrm{10 \%} \mathrm{KOH}$ in methanol, sonicated for 15 min followed by $90 \mathrm{~min}$ heat treatment at $70{ }^{\circ} \mathrm{C}$, and partitioned twice with $2 \mathrm{ml}$ cyclohexane. The combined cyclohexane phases were evaporated to dryness at $40{ }^{\circ} \mathrm{C}$ under $\mathrm{N}_{2}$. The samples were then dissolved in $500 \mu \mathrm{l}$ methanol, heated at $40{ }^{\circ} \mathrm{C}$ for $15 \mathrm{~min}$, filtered through a $0.45 \mu \mathrm{m}$ filter, and analyzed using HPLC with a UV detector $(282 \mathrm{~nm})$.

\subsection{Statistical analysis}

Normality and homogeneity of variances for all data were tested, and a log transformation was made when necessary. ANOVA-one way analysis was done to calculate differences between species. Pearson's correlation coefficients ( $r$ ) were calculated to quantify the linear relationship between parameters. Partial correlations were assessed to investigate possible influences of SOM content in the relationship between WR and pH, and also in the WR and GRSP and ergosterol. Statistical analyses were performed using the SPSS 11.5 package (CSPSS Inc., 1989).

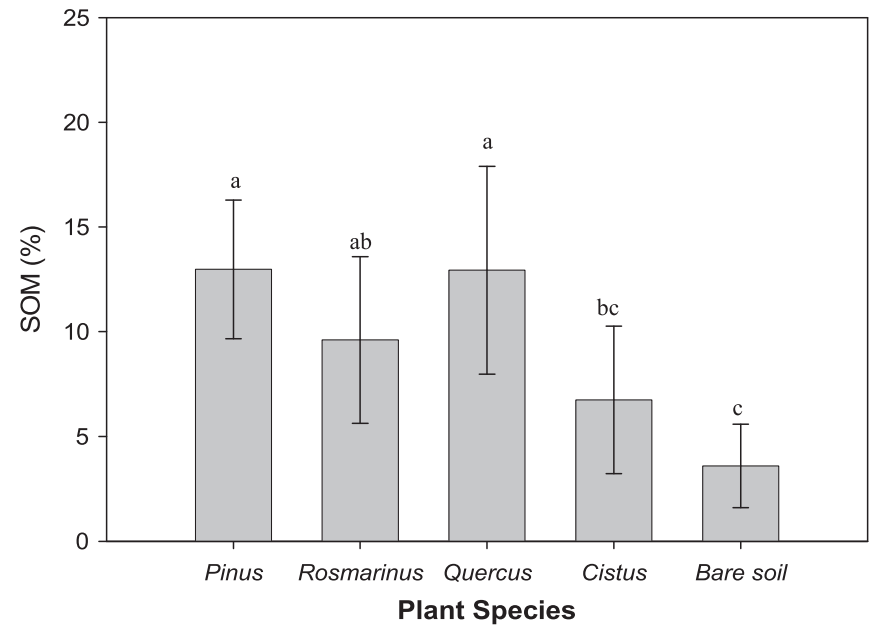

Fig. 2. SOM content beneath the different species and bare soil. Standard errors in bars. Different letters show the statistically significant differences between the different species and bare soil determined with the Tukey test $(P \leq 0.05)$.
Table 2

Pearson's correlation coefficients between WR and soil parameters for each species.

\begin{tabular}{|c|c|c|c|c|}
\hline & Species & SOM & $\mathrm{pH}$ & $\mathrm{pH}$ partial $(\mathrm{SOM})^{\mathrm{a}}$ \\
\hline \multirow[t]{4}{*}{ WR (log WDPT) } & Pinus & $0.855^{* *}$ & $-0.763^{* *}$ & -0.552 \\
\hline & Rosmarinus & $0.776^{* *}$ & $-0.833^{* *}$ & -0.766 \\
\hline & Quercus & $0.934^{* *}$ & -0.373 & n.c. ${ }^{b}$ \\
\hline & Cistus & n.c. ${ }^{c}$ & n.c. ${ }^{c}$ & n.c. ${ }^{\mathrm{c}}$ \\
\hline
\end{tabular}

a Coefficient of partial correlations between WR and pH controlling the effect of SOM.

b n.c.: partial correlation not calculated because of lack of correlation with $\mathrm{pH}$.

c n.c.: not calculated because of the absence of SWR under this plant species.

*******; significant at $\mathrm{P} \leq 0.001,0.01,0.05$ respectively.

\section{Results}

3.1. Soil water repellency distribution under different plant species and its relationship with SOM content

Our results of the WDPT showed that the $41 \%$ of the total samples were hydrophobic. The majority of water repellent samples were classified as slight or strongly water repellent (around 22\% and $14 \%$, respectively), while severe WR was only detected in 5\% of samples. No extreme water repellent sample was found. On the other hand, the occurrence of WR was different between species and was higher under Pinus (87\% of samples) and Quercus (60\% of samples). In Rosmarinus samples only $28 \%$ of the samples were repellent. All Cistus and bare soil samples were wettable. In spite of the high number of water repellent samples found under Pinus, the strongest persistence was found under Quercus (Fig. 1).

SOM content revealed significant differences between soils under different plant species (Fig. 2), being higher in samples of Pinus and Quercus, with mean values of $12.98 \%$ and $12.93 \%$ respectively. Positive significant correlations were found between WR and SOM content pooling the data of all species together $\left(r=0.867^{* *}\right)$ and separately for the species that showed samples with WR (Table 2 and Fig. 3), with the best correlations for Pinus and Quercus ( $\mathrm{r}=0.855^{* *}, \mathrm{r}=$ $0.934^{* *}$ respectively) (Fig. 3 ).

\subsection{Extractable lipid's content}

For this analysis, samples from eighteen soils under Pinus $(\mathrm{n}=8)$ and Quercus ( $\mathrm{n}=10$ ) very similar in SOM content but quite different in WR were selected to perform lipid extractions in order to check the role of the quality of SOM content in soil WR (Fig. 4). The concentrations of extractable lipids in the soils were $0.12 \pm 0.09 \%$ for Pinus and $0.12 \pm 0.10 \%$ for Quercus and achieved maximum values in repellent

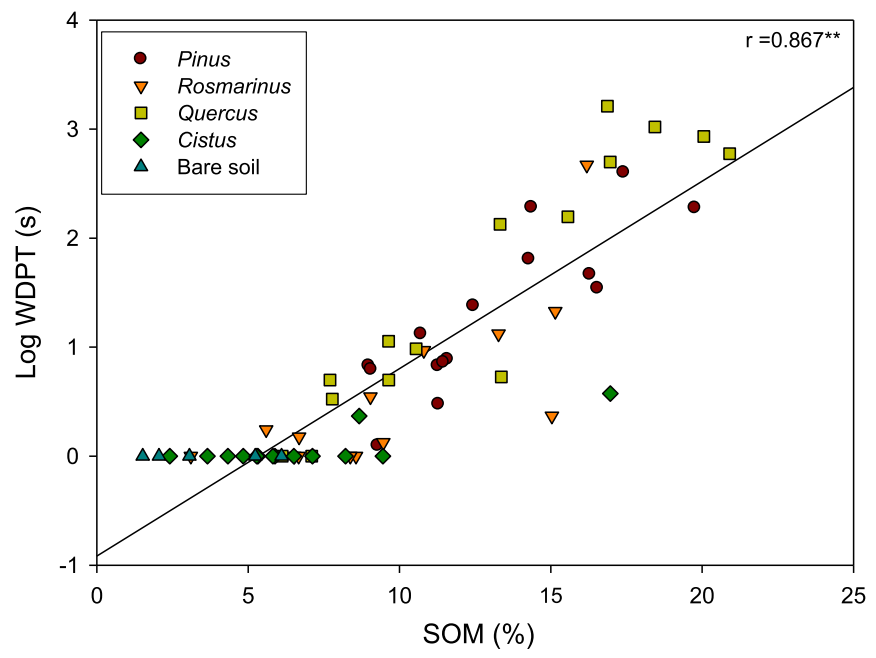

Fig. 3. Relationship between SOM content and WR (log WDPT) of samples taken beneath the different species and bare soil ( $\mathrm{r}=$ Pearson's correlation coefficient). 


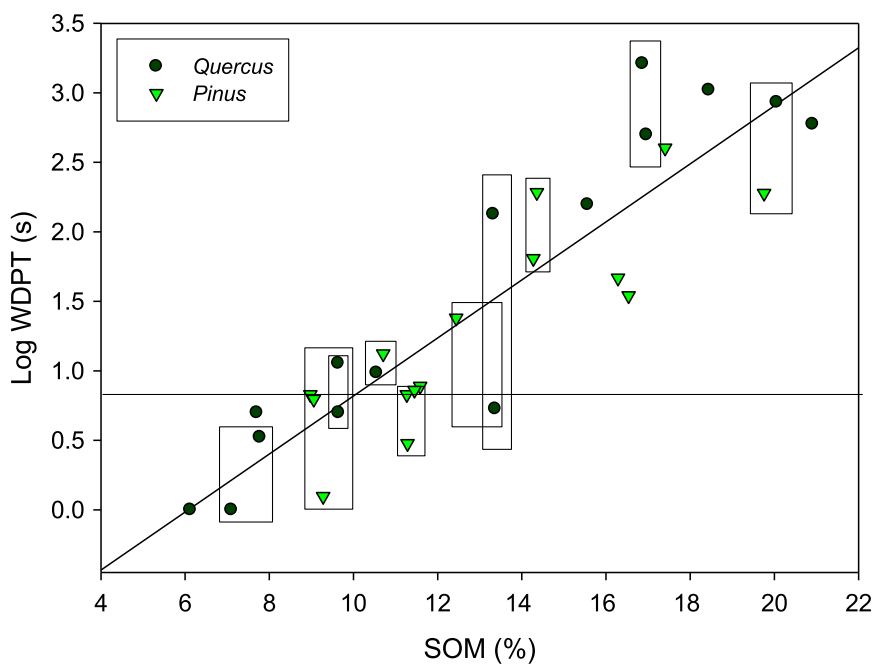

Fig. 4. Relationship between WR ( $\log$ WDPT) and SOM content of soil samples beneath Quercus and Pinus. Rectangles show samples selected with similar SOM content and different WR for extractable lipids analysis.

samples (Fig. 5). In fact, extractable lipid's content showed a close relationship with $\log$ WDPT $\left(r=0.858^{* *}\right)$ (Figs. 5 and 6$)$. The Pearson's correlation coefficients were also significantly high if analyzed per species (Pinus; $\mathrm{r}=0.753$ and Quercus $\mathrm{r}=0.953^{* *}$; Fig. 6).

\subsection{Water repellency persistence and $\mathrm{pH}$}

For all four species, $\mathrm{pH}$ values of water repellent samples were generally lower than those of wettable samples. The $\mathrm{pH}$ measured followed this order Pinus $=$ Quercus $<$ Rosmarinus $<$ Cistus $<$ bare soil. We found negative correlations with WR, although these correlations seem to be related to SOM content (Fig. 7) as the partial correlation showed (Table 2). In concrete, in samples under Pinus, that correlation was highly significant $\left(r=-0.763^{* *}\right)$, but disappears in the partial correlations $(\mathrm{r}=-0.552)$ indicating that it is an apparent correlation

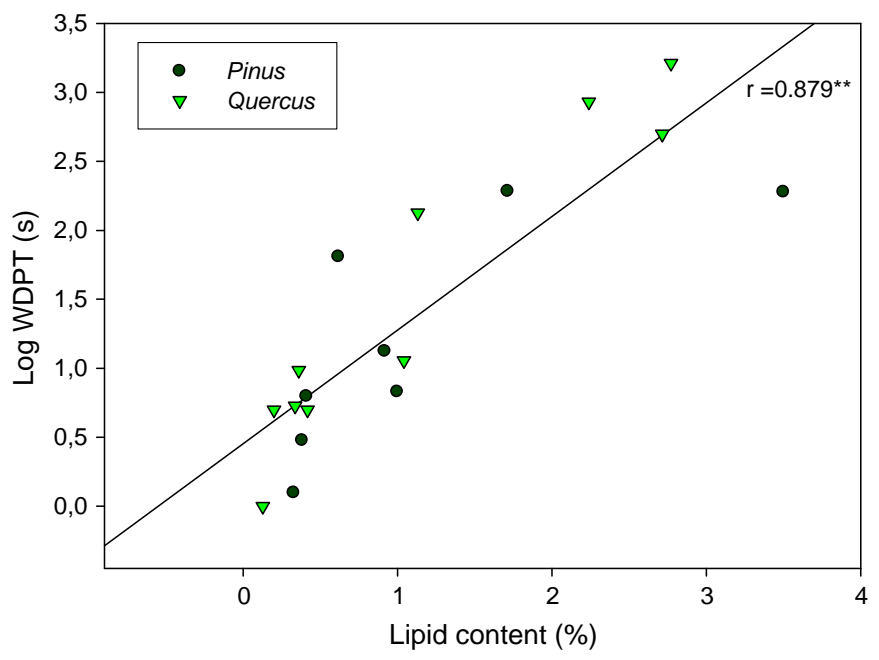

Fig. 6. Relationship between extractable lipid contents and WR (log WDPT) for the selected samples studied.

really controlled by SOM content. In contrast, samples under Quercus, in spite of having the same $\mathrm{pH}$ mean values as Pinus, had no correlation between these parameters (Table 2).

\subsection{Fungal related parameters: GRSP, mycelium length and ergosterol}

GRSP from AM fungi revealed significant differences between species (Fig. 8). The highest average content of GRSP was found in Rosmarinus (Fig. 8).

Between GRSP and SOM content, we found significant correlations except for Pinus, in spite of showing a clear tendency (Fig. 9). These correlations were especially high for bare soil $\left(\mathrm{r}=0.948^{*}\right)$, Quercus $\left(\mathrm{r}=0.868^{* *}\right)$ and Cistus $\left(\mathrm{r}=0.895^{* *}\right)$ (Table 3$)$.

Pearson's correlations were also significant between WR and GRSP (Table 3). The higher correlations corresponded to samples of Quercus $\left(\mathrm{r}=0.763^{* *}\right)$. Cistus and bare soil were not calculated because there

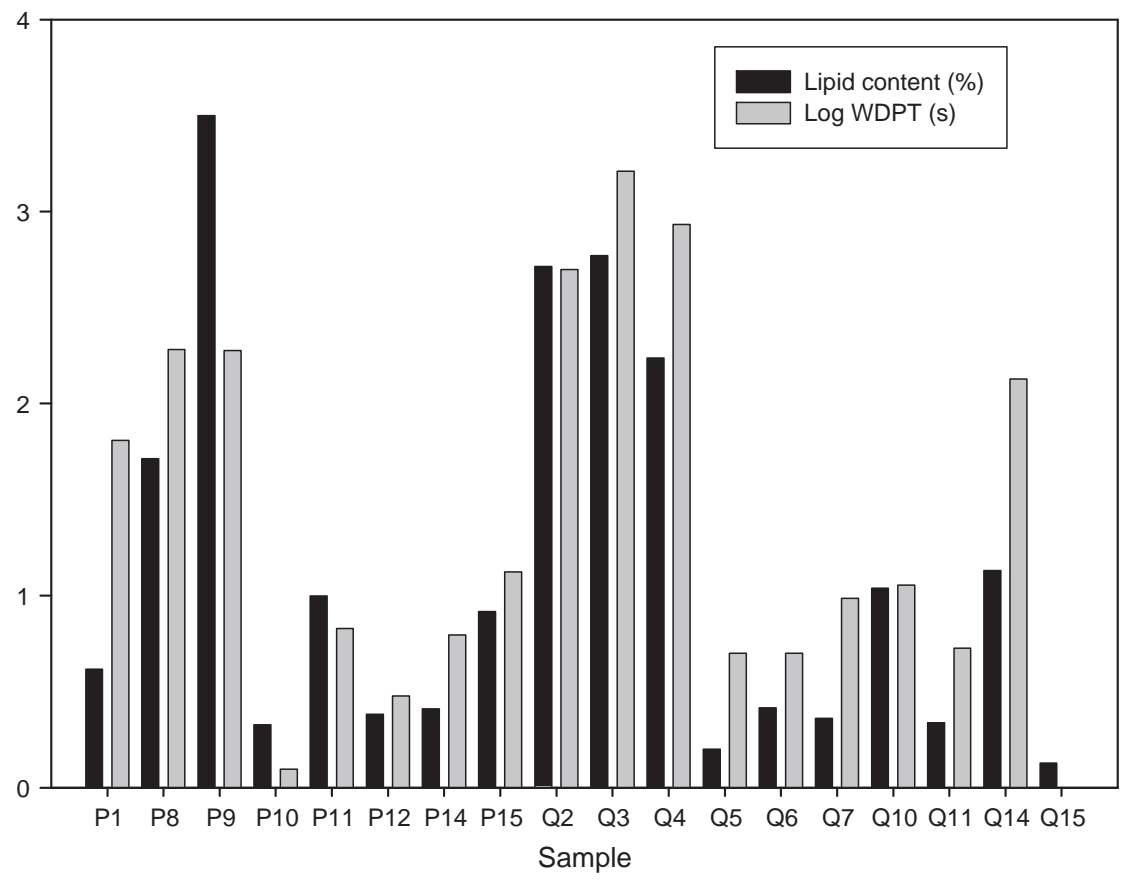

Fig. 5. WR and extractable lipid content for selected samples studied. ( $\mathrm{P}=$ Pinus and $\mathrm{Q}=$ Quercus, numbers correspond with the name of sample). 


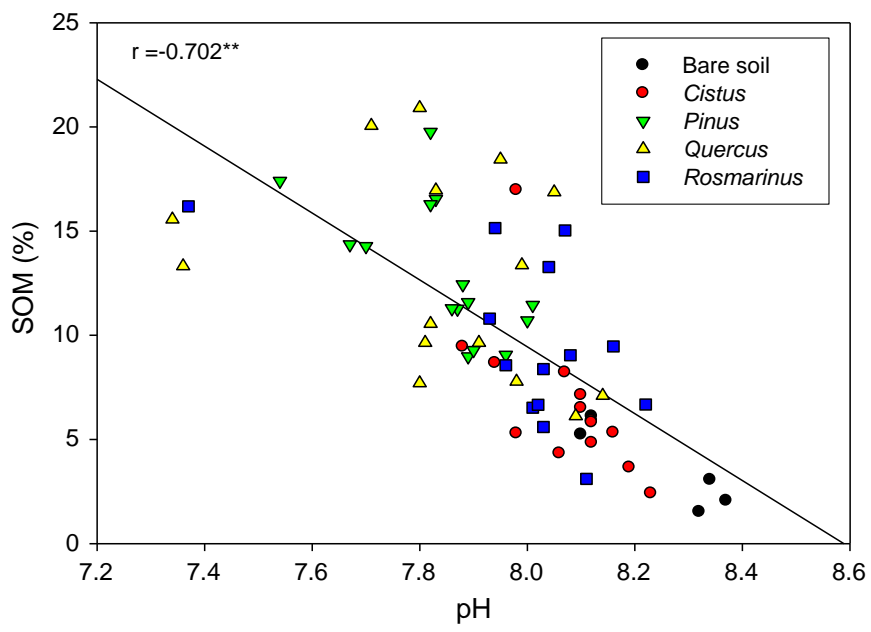

Fig. 7. Relationship between $\mathrm{pH}$ and SOM content of samples taken beneath the different species and bare soil.

were no water repellent samples in those groups (Table 3). Nevertheless, this relationship seems to be controlled by SOM as partial correlations indicate, with the exception of Pinus (Table 3).

In univariate ANOVA tests, differences in mycelium length were significant between groups $(\mathrm{P}<0.05)$. Species with the most mycelium length were Pinus and Quercus and the less Cistus (Fig. 10). Pearson's correlation coefficients between mycelium length and WR, SOM content, $\mathrm{pH}$ and GRSP were not significant.

Differences between species were also found for ergosterol content. Mean content followed this order Pinus $>$ Quercus $>$ Rosmarinus $>$ Cistus $>$ bare soil (Fig. 11). Pearson's correlation coefficients with WR were significant (Table 4). In the case of Pinus, the relationship was especially strong (Fig. 12) and did not disappear when we analyzed the partial correlation controlling SOM (Table 4). This is not the case with the rest of the species where the correlation between WR and ergosterol disappeared in the partial correlation controlling the effect of SOM (Table 4). Results revealed a relationship with GRSP for Quercus ( $\mathrm{r}=0.681^{* *}$ ) and particularly for Rosmarinus samples $\left(\mathrm{r}=0.895^{* *}\right)$ (Fig. 13).

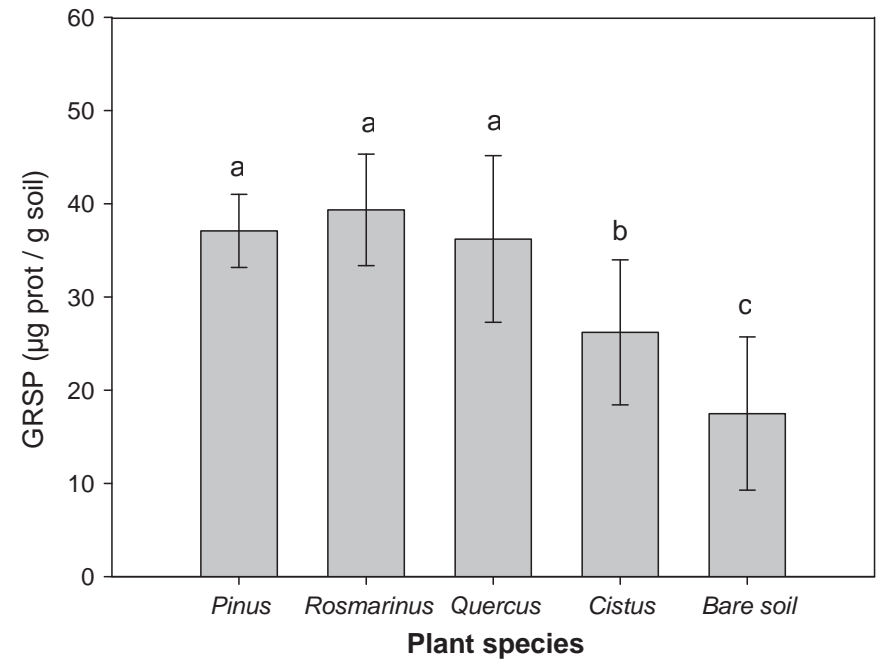

Fig. 8. GRSP content beneath the different species and bare soil. Standard errors in bars. Different letters show the statistically significant differences between the different species and bare soil with the Tukey test $(P \leq 0.05)$.

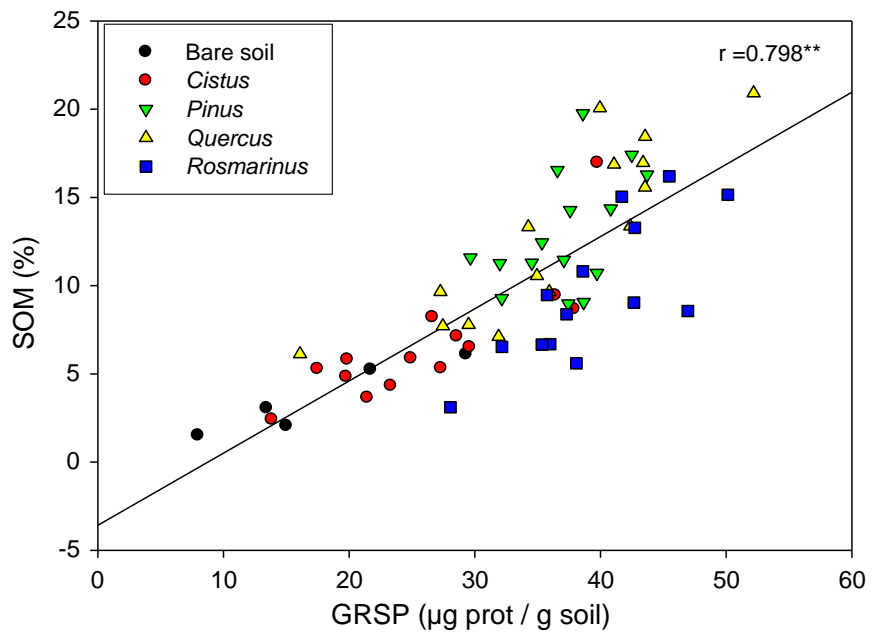

Fig. 9. Relationship between GRSP and SOM content beneath the different species and bare soil.

\section{Discussion}

Soil WR patchy distribution has already been reported in a large quantity of works carried out in forest soils in Mediterranean ecosystems (Martínez-Zavala and Jordán-López, 2009; Mataix-Solera et al., 2007). In agreement with these researches, our results showed a high variability in persistence of WR, around $41 \%$ of samples were repellent, and the influence of SOM content on soil WR was evident ( $r=0.872$ (Fig. 3)). Persistence of WR was dependent on the influence of plant species. Depending on this factor, soil will be provided with a different input of organic compounds. In general, evergreen trees supply soil with considerably more organic material than shrubs, so as it was expected, we found the highest water repellent samples and total SOM content under the tree species studied (Pinus and Quercus). Severe soil WR can be induced by a high number of phenolic compounds found in the composition of leaves and plant tissues of oaks (Conde et al., 1998; Salminen et al., 2004) and resins, waxes, aromatic oils, and other substances in pines (Doerr et al., 1998).

Pinus is one of the genera that have received most attention for its influence in the development of soil WR as much in Mediterranean ecosystems (Doerr et al., 2000) as in other ones (Buczko et al., 2002; Lichner et al., 2012). However, the influence of Q. rotundifolia in WR has still not been described, although there are studies in which soil WR is associated with different species of Quercus evergreen trees (Doerr et al., 2000; Jordán et al., 2008) and shrubs (Arcenegui et al., 2008; Gimeno-García et al., 2011). A positive relationship between SOM content and WR has been reported several times (Mataix-Solera and Doerr, 2004; Mataix-Solera et al., 2007), especially if samples have been taken from the same soil type and beneath the same plant species. In other cases, poor or no significant

Table 3

Pearson's correlation coefficients between GRSP and soil parameters for each species.

\begin{tabular}{lllll}
\hline & Species & SOM & $\begin{array}{l}\text { WR } \\
(\log \text { WDPT })\end{array}$ & $\begin{array}{l}\text { WR partial } \\
(\text { SOM })^{\mathrm{a}}\end{array}$ \\
\hline GRSP & Pinus & 0.491 & $0.674^{* *}$ & 0.563 \\
& Rosmarinus & $0.626^{* *}$ & $0.533^{*}$ & -0.012 \\
& Quercus & $0.868^{* *}$ & $0.763^{* *}$ & -0.271 \\
& Cistus & $0.895^{* *}$ & n.c. & n.c. ${ }^{\text {b }}$ \\
& Bare soil & $0.948^{*}$ & n.c. & n.c. \\
\hline
\end{tabular}

a Coefficient of partial correlations between GRSP and WR (log WDPT) controlling the effect of SOM.

b n.c.: not calculated because of the absence of SWR under this plant species and bare soil.

*******; significant direfences at $\mathrm{P} \leq 0.001,0.01,0.05$ respectively. 


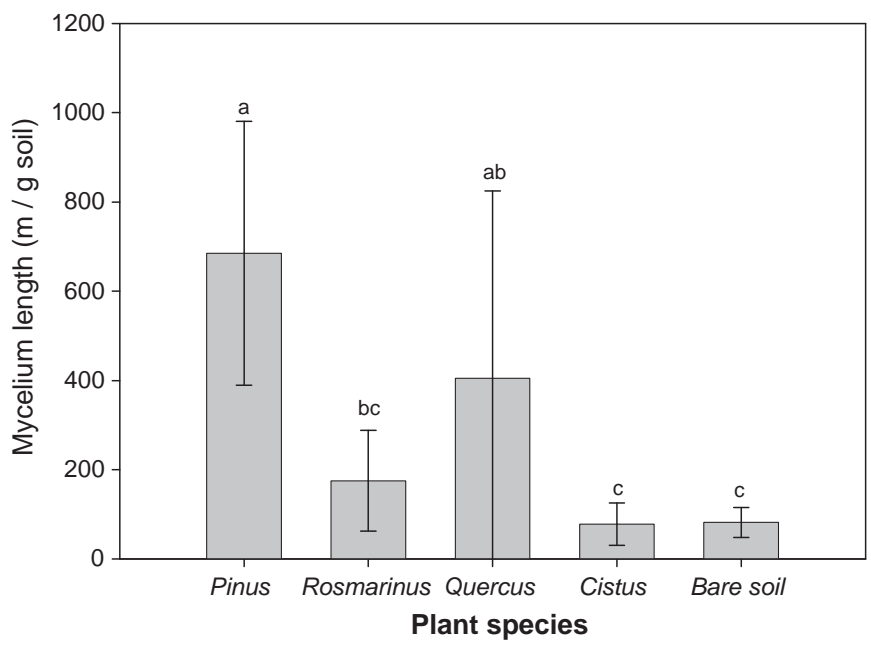

Fig. 10. Mycelium length beneath the different species and bare soil. Standard errors in bars. Different letters show the statistically significant differences between the different species and bare soil with the Tukey test $(\mathrm{P} \leq 0.05)$.

correlations between SOM content and WR have also been reported (DeBano, 1981; Ritsema and Dekker, 1994; Scott, 2000). This inconsistency has been attributed to the fact that only a small amount of compounds of SOM is really implicated in WR (Mataix-Solera and Doerr, 2004; Zavala et al., 2009). WR might be controlled by the type and quality of organic matter rather than by its amount (DeBano et al., 1970; Wallis and Horne, 1992). In fact, we observed a different pattern of WR persistence between Quercus and Pinus despite having similar SOM content.

Lipid fraction has been commonly linked with hydrophobicity (DeBano, 2000). Our results of extractable lipid's content would corroborate that hypothesis (Fig. 5). Strong correlations between extractable lipid's content and WR for Quercus and Pinus samples establish a clear relationship (Figs. 5 and 6). Different concentrations in extractable lipid content could explain differences in WR persistence of samples from the same plant species. In agreement with us, De Blas et al. (2010) reported the effect of lipid humic fractions on soil WR. They found the free lipid fraction to be the most relevant soil fraction inducing WR, although, they also outlined the importance of the particulate organic matter and extractable humic acids. Different patterns of persistence of soil WR observed between

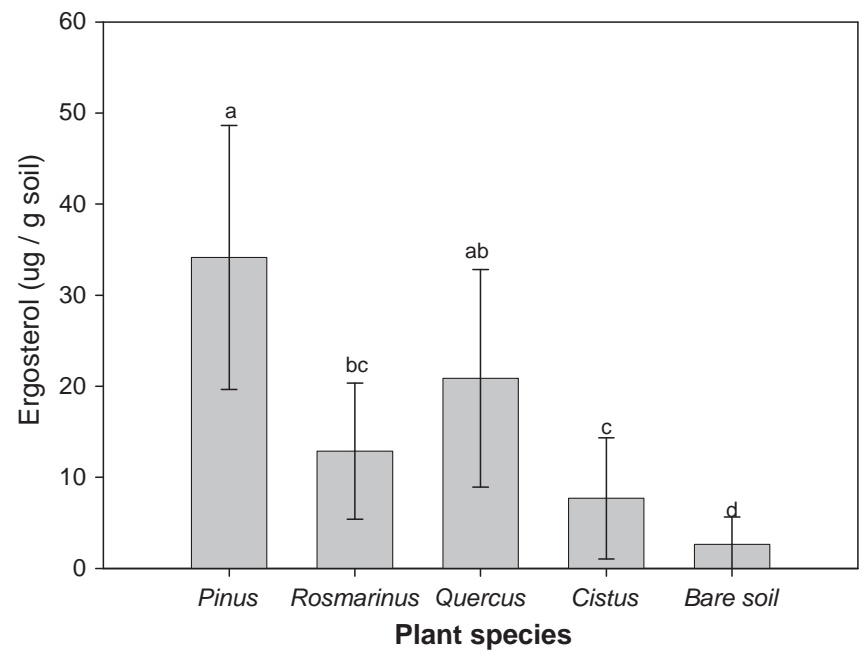

Fig. 11. Ergosterol content beneath the different species and bare soil. Standard errors in bars. Different letters show the statistically significant differences between the different species and bare soil with the Tukey test $(\mathrm{P} \leq 0.05)$.
Table 4

Pearson's correlation coefficients between ergosterol (log EG) and WR (log WDPT) for each species.

\begin{tabular}{llll}
\hline Species & $\begin{array}{l}\text { WR } \\
(\log \text { WDPT })\end{array}$ & $\begin{array}{l}\text { WR partial } \\
(\text { SOM })^{\mathrm{a}}\end{array}$ \\
\hline Ergosterol (log EG) & Pinus & $0.905^{* *}$ & $0.861^{* *}$ \\
& Rosmarinus & $0.744^{* *}$ & 0.243 \\
& Quercus & $0.672^{*}$ & 0.331 \\
& Cistus & n.c. & n.c. $^{{ }^{\text {b }}}$ \\
& Bare soil & n.c. & n.c. \\
\hline
\end{tabular}

\footnotetext{
a Coefficient of partial correlations between ergosterol and WR (log WDPT) controlling the effect of SOM.

b n.c.: not calculated because of the absence of SWR under this plant species and bare soil.

******; significant at $\mathrm{P} \leq 0.001,0.01,0.05$ respectively.
}

Quercus and Pinus samples might be due to differences in composition of specific kind of lipids (fatty acids, sterols, waxes etc.) in their own organic materials. However, Horne and McIntosh (2000) did not find a clear correlation between WR with organic carbon content and with the quantity of lipid or any lipid fraction in New Zealand water repellent sandy soils. They suggested that the severity of repellency was not influenced by the total amount of lipids or any lipid fraction in the bulk soil but rather by orientation of amphipathic compounds. Samples for those studies were taken under very different plant covers; Pinus and Eucalyptus (De Blas et al., 2010) and different grass covers (Horne and McIntosh, 2000), so the origin and in turn the quality of SOM and its particular interaction with the chemical components of the surface could explain these differences. Thus, it would be interesting to know more about differences in extractable lipids and organic fractions between species to evaluate their possible specific influence on soil WR. It could be also interesting to compare the interaction of these organic compounds with soils of different properties in their inorganic fraction (clay content, mineralogy, etc.).

The number of soil water repellent samples beneath Rosmarinus was significantly lower than Pinus and Quercus. Lower input of organic compounds to the soil would be the most consistent explanation. However, it is not so low, if we compare it with the results obtained by Gimeno-García et al. (2011) or Mataix-Solera et al. (2007), who found around $4 \%$ and $5 \%$ of water repellent samples respectively under this species. Mataix-Solera et al. (2007) carried out their study in the same area as ours. The differences in severity of WR could be due to soil moisture and SOM content and its quality. In fact, if we compare both SOM content under Rosmarinus, we will observe that their data varied from 7.1 to 9.6, while our data goes from 7.9 to 13.86 (for wettable and water repellent samples, respectively). Our results would not be unusual if we took into account that Rosmarinus has a high relative wax input rate, which is based on leaf wax contents and characteristics of the ectorganic profile. That could be responsible for soil WR (Mataix-Solera et al., 2007; Verheijen and Cammeraat, 2007).

On the other hand, organic material can influence $\mathrm{pH}$, which could be strongly involved in the development of soil WR. Our results showed the lowest $\mathrm{pH}$ in the most repellent samples, Pine and Quercus, which are the species with the highest SOM content. Organic materials would explain both differences in $\mathrm{pH}$ among species and the relationship between $\mathrm{pH}$, SOM content and WR. In common with other authors (Martínez-Zavala and Jordán-López, 2009; Mataix-Solera et al., 2007) we found a negative correlation between these parameters, i.e., repellency increases as $\mathrm{pH}$ reduces. Nevertheless, in agreement with these studies, the relationship seems to be influenced by SOM, as the partial correlations showed.

Traditionally, soil WR has been associated with acidic soil, although it has already been reported in alkaline soils (Arcenegui et al., 2008; Mataix-Solera et al., 2007). Graber et al. (2009) concluded that soil WR can develop in alkaline to neutral soils where $\mathrm{Ca}^{+2}$ ions are abundant, which are capable of interacting with fatty acids. That is in accordance with the model proposed by Diehl et al. (2010), in which the 

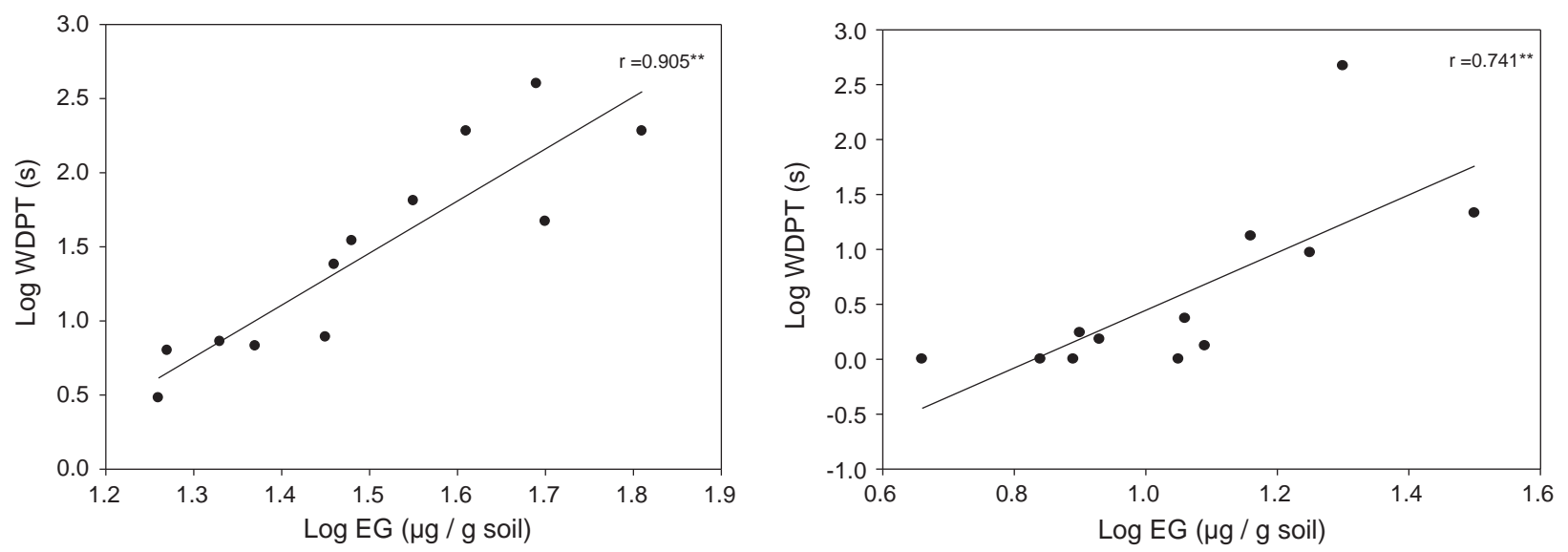

Fig. 12. Relationship between WR (log WDPT) and ergosterol (log EG) beneath Pinus (left) and Rosmarinus (right).

relationship between soil WR and $\mathrm{pH}$ changes depends on an abundance of active protons (in our case it would be $\mathrm{Ca}^{+2}$ ) and the organic matter functional groups, like fatty acids. The fatty acid structure is one of the most fundamental categories of biological lipids, and is commonly used as a building block of more structurally complex lipids. So, in accordance with that model, our results would explain the relationship not only between $\mathrm{pH}$, SOM content and WR, but also in the case of Pinus, with lipid content too. In our case differences in organic functional groups could be an explanation for absence of correlation beneath Quercus with $\mathrm{pH}$ and the rest of the parameters.

According to other studies, soil WR can however be caused by the activity of soil organisms. Studies found water repellency is closely associated with fungal growth and soil microorganisms (Jex et al., 1985; Rillig, 2005). Rillig et al. (2010) obtained a direct causal link between the growth of AMF mycelium and soil WR under laboratory conditions. However, Hallett et al. (2009), under controlled conditions too, did not find a clear relationship. We also failed to find such a link at least in the first $\mathrm{cm}$ of soil depth. Our study measured mycelium length in soil, not only AMF mycelium, and the results suggest that not all fungal mycelium could be contributing in the same way to WR. Nevertheless, in general, our results seem to link stronger WR with fungal activity through the measurements of other related parameters (GRSP and ergosterol) instead of mycelium length. Similar relationships for GRSP and ergosterol were obtained by Young et al. (2012) in two different ecosystems: grassland and an arable soil. On the other hand, under controlled laboratory conditions in which a specific AM fungus was

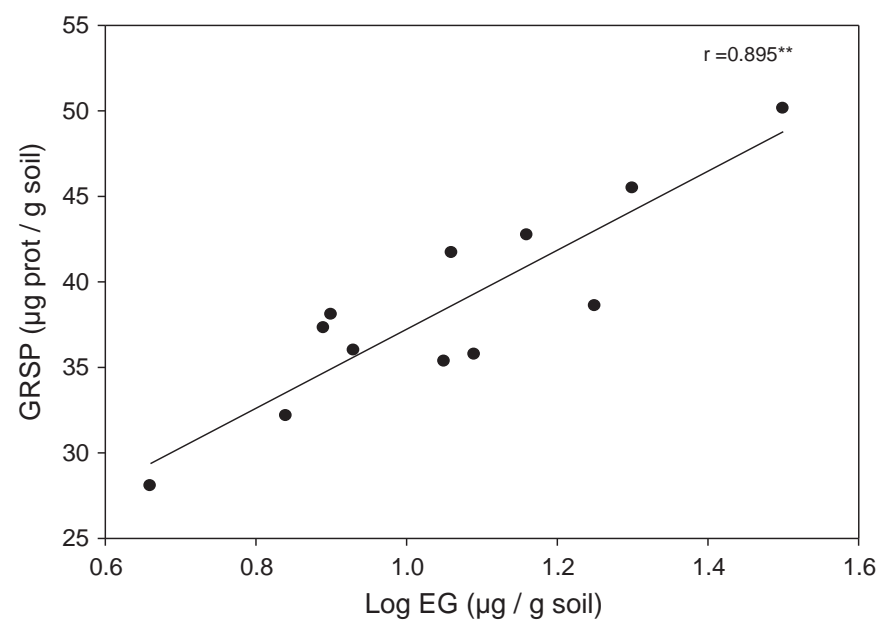

Fig. 13. Relationship between GRSP and ergosterol (log EG) beneath Rosmarinus. introduced, Feeney et al. (2004) and Hallett et al. (2009) did not find that link with glomalin and ergosterol respectively. The reason might lie in our analytical method (Bradford protein assay). With samples taken under field conditions, we could have measured protein compounds from a large diversity of AM fungi and maybe non-fungi derived compounds, as pointed out by Young et al. (2012); so that question remains still unclear.

In this study, we have tried to cover a large range of different fungal parameters in our analyses; AM fungi activity (GRSP), the total life fungal biomass (ergosterol) and mycelium length in soil. Every parameter offers us different information, so it is quite normal, especially in our case, that weak correlations were found between mycelium length with GRSP and ergosterol. In the case of GRSP neither Borie et al. (2000) nor Rillig and Steinberg (2002) detected it. Production rates of glomalin are not always correlated with AM abundance (Treseder and Turner, 2007). Regarding ergosterol, normally active mycelium does not correspond with mycelium length in soils.

Soil microbial biomass and its activity are influenced by the SOM content (Goberna et al., 2006). In fact, in our study, the link between fungal activity and soil WR (at least under Quercus and Rosmarinus) appears to be influenced by them (Tables 3 and 4). Nevertheless, under Pinus we didn't find that correlation. We hypothesize that this relationship could be related more to the quality of SOM, in concrete with extractable lipids. Pinus obtained the biggest ergosterol content and mycelium length, this might be due to differences in SOM quality. Fungal:bacteria activity increases when soil C:N ratio increases (Kuijper et al., 2005). That suggests possible significant differences in C:N ratios between species. In Díaz-Pinés et al. (2011) C:N ratios obtained were higher under pine than under oak in a Mediterranean ecosystem. Those results support our results regarding the indirect relationship between fungal activity and WR as a consequence of the quality of SOM. Pinus and Quercus probably promote different microbial environments. How long lipids remain as free fractions will depend on their activity. Decomposition regimes could be also essential in the development and appearance of WR through the accumulation of polar substances (Franco et al., 2000).

On the other hand, the biggest glomalin content corresponded to samples of Rosmarinus (Fig. 8). This result is logical as Rosmarinus is the only species in this study, which is associated particularly with AM fungi. These results might suggest a possible non-influence of GRSP in soil WR, at least for the studied soil depth.

Nevertheless, it would be interesting to know more about differences in microbial environment beneath these species. More work would be required to characterize possible specific fungal and bacterial species responsible for inducing WR; in particular what specific compounds are really involved in the development of soil WR. Our aim here was to study top-soil WR after the dry season, so maybe the fungal 
activity detected here is not enough to be the main factor involved in the soil WR at this soil depth $(0-2.5 \mathrm{~cm})$. It could be also interesting to study their possible influence in soil WR in other seasons and depths.

\section{Conclusions}

Water repellency is a complex phenomenon affected by a large quantity of soil parameters, which in turn are inter-connected. Thus, in our study we have tried to explain what are the main factors involved in its development in the top-soil layer. According to our results, in this environment and under these conditions, the quality of soil organic matter could be the major responsible factor. All the rest of the parameters studied here seem to depend on it. In concrete, extractable lipids seem to be the principal factor.

Apart from Pinus, fungal biomass appears to be related with SOM content. Soil WR found under Pinus seems to be the most influenced by fungi. Quality of SOM could be responsible for that. Presence or quantity of determined fungi or microorganisms might be related with the composition of SOM. The persistence and permanence of soil WR could be determined by specific fungi through their role in the decomposition regimen. How long lipids remain as free fraction and accumulations of polar substances will depend on their activity.

Finally, if top-soil WR is caused by a fraction of SOM, the hypothesis of a possible ecological plant strategy makes it more acceptable. It would explain why WR appears in semiarid environments where improving water conservation is essential. Having patchy water repellent distribution in its area of influence could contribute to both channeling water deep into the soil profile to conserve it in depth near to their rhizosphere, and at the same time reducing top-soil evaporation rates.

\section{Acknowledgments}

This research has been supported by the Spanish "Ministerio de Economía y Competitividad" through the HYDFIRE project CGL201021670-C02-01 and GEOFIRE project CGL2012-38655-C04-01. Elena Lozano and Patricia Jiménez-Pinilla acknowledge the "Generalitat Valenciana" and the "Ministerio de Economía y Competitividad" of Spain for their respective grants. The authors also thank the MED_Soil research group for its hospitality, Nicasio T. Jiménez for his help during lipid's extraction and Francis Young for improving the English language of this manuscript.

\section{References}

Arcenegui, V., Mataix-Solera, J., Guerrero, C., Zornoza, R., Mataix-Beneyto, J., GarciaOrenes, F., 2008. Immediate effects of wildfires on water repellency and aggregate stability in Mediterranean calcareous soils. Catena 74, 219-226.

Bååth, E., Söderström, B., 1980. Comparison of two methods for the estimation of soil fungal lengths. Soil Biology and Biochemistry 12, 385-387.

Bardgett, R.D., 1991. The use of the membrane filter technique for comparative measurements of hyphal lengths in different grassland sites. Agriculture, Ecosystems and Environment 34 (1-4), 115-119.

Bisdom, E.B.A., Dekker, L.W., Schoute, J.F.T., 1993. Water repellency of sieve fractions from sandy soils and relationships with organic material and soil structure. Geoderma 56, 105-118.

Borie, F., Rubio, R., Rouanet, J.L., Morales, A., Castillo, C., 2000. Relación entre longitud de hifas de hongos micorrizógenos arbusculares y producción de glomalina con las características físicas y químicas de suelos bajo Cero Labranza. Revista Chilena de Historia Natural 73, 749-756.

Buczko, U., Bens, O., Fischer, H., Hüttl, R.F., 2002. Water repellency in sandy luvisols under different forest transformation stages in northeast Germany. Geoderma $109,1-18$

Buyer, J.S., Zuberer, D.A., Nichols, K.A., Franzluebbers, A., 2011. Soil microbial community function, structure and glomalin in response to tall fescue endophyte infection. Plant and Soil 339, 401-412.

Conde, E., Cadahía, E., García-Vallejo, M.C., Fernández de Simón, B., 1998. Polyphenolic composition of Quercus suber cork from different Spanish provenances. Journal of Agricultural and Food Chemistry 46, 3166-3171.

De Blas, E., Rodríguez-Alleres, M., Almendros, G., 2010. Speciation of lipid and humic fractions in soils under pine and eucalyptus forest in northwest Spain and its effect on water repellency. Geoderma 155, 242-248.
DeBano, L.F., 1981. Water repellent soils: a state-of-the-art. USDA Forest Service General Technical Report, PSW-46, Berkeley.Pacific Southwest Forest and Range Experiment Station, California 21.

DeBano, L.F., 2000. Water repellency in soils: a historical overview. Journal of Hydrology 231-232, 4-32.

DeBano, L.F., Mann, L.D., Hamilton, D.A., 1970. Translocation of hydrophobic substances into soil by burning organic litter. Soil Science Society of America Proceedings 34, $130-133$.

Dekker, L.W., Ritsema, C.J., 1994. How water moves in a water repellent sandy soil: 1. Potential and actual water repellency. Water Resources Research 30, 2507-2517.

Díaz-Pinés, E., Rubio, A., Van Miegroet, H., Montes, F., Benito, M., 2011. Does tree species composition control soil organic carbon pools in Mediterranean mountain forests? Forest Ecology and Management 262, 1895-1904.

Diehl, D., Bayer, J.V., Woche, S.K., Bryant, R., Doerr, S.H., Schaumann, G.E., 2010. Reaction of soil water repellency to artificially induced changes in soil pH. Geoderma 158, 375-384.

Doerr, S.H., Shakesby, R.A., Walsh, R.P.D., 1998. Spatial variability of soil hydrophobicity in fire-prone eucalyptus and pine forests, Portugal. Soil Science 163, 313-324.

Doerr, S.H., Shakesby, R.A., Walsh, R.P.D., 2000. Soil water repellency: its causes, characteristics and hydro-geomorphological significance. Earth-Science Reviews 51, 33-65.

Doerr, S.H., Douglas, P., Evans, R.C., Morley, C.P., Mullinger, N.J., Bryant, R., Shakesby, R.A., 2005a. Effects of heating and post-heating equilibration times on soil water repellency. Australian Journal of Soil Research 43, 261-267.

Doerr, S.H., Llewellyn, C.T., Douglas, P., Morley, C.P., Mainwaring, K.A., Haskins, C., Johnsey, L., Ritsema, C.J., Stagnitti, F., Allison, G., Ferreira, A.J.D., Keizer, J.J., Ziogas, A.K., Diamantes, J., 2005b. Extraction of compounds associated with water repellency in sandy soils of different origin. Australian Journal of Soil Research 43, 225-237.

Driver, J.D., Holben, W.E., Rillig, M.C., 2005. Characterization of glomalin as a hyphal wall component of arbuscular mycorrhizal fungi. Soil Biology and Biochemistry 37, 101-106.

Feeney, D.S., Daniell, T., Hallett, P.D., Illian, J., Ritz, K., Young, I.M., 2004. Does the presence of glomalin relate to reduced water infiltration through hydrophobicity? Canadian Journal of Soil Science 84, 365-372.

Franco, C.M.M., Tate, M.E., Oades, J.M., 1994. The development of water repellency in sands: studies on the physico-chemical and biological mechanisms. Proceedings of the 2nd National Water Repellency Workshop. Perth, Western Australia, pp. 18-30.

Franco, C.M.M., Tate, M.E., Oades, J.M., 1995. Studies on non-wetting sands. I. The role of intrinsic particulate organic matter in the development of water repellency on nonwetting sands. Australian Journal of Soil Research 33, 253-263.

Franco, C.M.M., Clarke, P.J., Tate, M.E., Oades, J.M., 2000. Studies on non-wetting sands: II. Hydrophobic properties and chemical characterisation of natural water-repellent materials. Journal of Hydrology 231-232, 47-58.

Fridland, Y.V., 1982. Some characteristics of soil lipids as a function of ecological conditions. Soviet Soil Science 14, 80-88.

Gimeno-García, E., Pascual, J.A., Llovet, J., 2011. Water repellency and moisture content spatial variations under Rosmarinus officinalis and Quercus coccifera in a Mediterranean burned soil. Catena 85, 48-57.

Goberna, M., Sánchez, J., Pascual, J.A., García, C., 2006. Surface and subsurface organic carbon, microbial biomass and activity in a forest soil sequence. Soil Biology and Biochemistry 38, 2233-2243.

González-Vila, F.J., Polvillo, O., Boski, T., Moura, D., de Andrés, J.R., 2003. Biomarker patterns in a time-resolved Holocene/terminal Pleistocene sedimentary sequence from the Guadiana river estuarine area (SW Portugal/Spain border). Organic Geochemistry $34,1601-1613$

Graber, E.R., Tagger, S., Wallach, R., 2009. Role of divalent fatty acid salts in soil water repellency. Soil Science Society of America Journal 73, 541-549.

Hallett, P.D., Young, I.M., 1999. Changes to water repellence of soil aggregates caused by substrate-induced microbial activity. European Journal of Soil Science 50, 35-40.

Hallett, P.D., Feeney, D.S., Bengough, A.G., Rillig, M.C., Scrimgeour, C.M., Young, I.M., 2009. Disentangling the impact of AM fungi versus roots on soil structure and water transport. Plant and Soil 314, 183-196.

Hanssen, J.F., Thingstad, T.F., Goksøyr, J., 1974. Evolution of the hyphal length and fungal biomass in soil by a membrane filter technique. Oikos 25, 102-107.

Horne, D.J., McIntosh, J.C., 2000. Hydrophobic compounds in sands in New Zealand: extraction, characterization and proposed mechanisms for repellency expression. Journal of Hydrology 231-232, 35-46.

Hudson, R.A., Traina, S.J., Shane, W.W., 1994. Organic matter comparison of wettable and non-wettable soils from bentgrass sand greens. Soil Science Society of America Journal 58, 361-367.

Jex, G.W., Bleakley, B.H., Hubbell, D.H., Munro, L.L., 1985. High humidity-induced increase in water repellency in some sandy soils. Soil Science Society of America Journal 49, 1177-1182.

Jordán, A., Martínez-Zavala, L., Bellinfante, N., 2008. Heterogeneity in soil hydrological response from different land cover types in southern Spain. Catena 74, 137-143.

Kuijper, L.D.J., Berg, M.P., Morrien, E., Kooi, B.W., Verhoef, H.A., 2005. Global change effects on a mechanistic decomposer food web model. Global Change Biology 11, 249-265.

Lichner, L., Holko, L., Zhukova, N., Schacht, K., Rajkai, K., Fodor, N., Sándor, R., 2012. Plants and biological soil crust influence the hydrophysical parameters and water flow in an aeolian sandy soil. Journal of Hydrology and Hydromechanics 4, 309-318.

Ma'shum, M., Tate, M.E., Jones, G.P., Oades, J.M., 1988. Extraction and characterization of water-repellent materials from Australian soils. Journal of Soil Science 39, 99-110.

Martínez-Zavala, L., Jordán-López, A., 2009. Influence of different plant species on water repellency in Mediterranean heathland soils. Catena 76, 215-223.

Mataix-Solera, J., Doerr, S.H., 2004. Hydrophobicity and aggregate stability in calcareous topsoils from fire-affected pine forest in the south-east of Spain. Geoderma 118, 77-88. 
Mataix-Solera, J., Arcenegui, V., Guerrero, C., Mayoral, A.M., Morales, J., González, I., García-Orenes, F., Gómez, I., 2007. Water repellency under different species in a calcareous forest soil in a semiarid Mediterranean environment. Hydrological Processes 58, 1254-1259.

McIntosh, J.C., Horne, D.J., 1994. Causes of repellency: I. The nature of the hydrophobic compounds found in a New Zealand development sequence of yellow-brown sands. Proceedings of the 2nd National Water Repellency Workshop. Perth, Western Australia, pp. 8-12.

Montgomery, H.J., Monreal, C.M., Young, J.C., Seifert, K.A., 2000. Determination of fungal biomass from ergosterol analyses. Soil Biology and Biochemistry 32, 1207.

Moore, G., Blackwell, P., 1998. Water repellence. In: Moore, G. (Ed.), Soil guide: a handbook for understanding and managing agricultural soils. Agriculture Western Australia Bulletin No. 4343, Perth, WA, pp. 53-63.

Morales, V.L., Parlange, J.Y., Steenhuis, T.S., 2010. Are preferential flow paths perpetuated by microbial activity in the soil matrix? A review. Journal of Hydrology 393, 29-36.

Rillig, M.C., 2005. A connection between fungal hydrophobins and soil water repellency. Pedobiologia 49, 395-399.

Rillig, M.C., Steinberg, P.D., 2002. Glomalin production by an arbuscular mycorrhizal fungus: a mechanism of habitat modification. Soil Biology and Biochemistry 34, 1371-1374.

Rillig, M.C., Mardatin, N.F., Leifheit, E.F., Antunes, P., 2010. Mycelium of arbuscular mycorrhizal fungi increases soil water repellency and is sufficient to maintain water-stable soil aggregates. Soil Biology and Biochemistry 42, 1189-1191.

Ritsema, C.J., Dekker, L.W., 1994. How water moves in a water repellent sandy soil: 2. Dynamics of fingered flow. Water Resources Research 30, 2519-2531.

Robinson, D.A., Lebron, I., Ryel, R.J., Jones, S.B., 2010. Soil water repellency: a method of soil moisture sequestration in pinyon-juniper woodland. Soil Science Society of America Journal 74 (2), 624-634.

Rodriguez-Iturbe, I., 2000. Ecohydrology: a hydrologic perspective of climate-soilvegetation dynamics. Water Resources Research 36 (1), 3-9.

Rousk, J., Bååth, E., 2007. Fungal biomass production and turnover in soil estimated using the acetate-in-ergosterol technique. Soil Biology and Biochemistry 39, 2173-2177.

Rumpel, C., Seraphin, A., Goebel, M.-O., Wiesenberg, G., González-Vila, F., Bachmann, J., Schwark, L., Michaelis, W., Mariotti, A., Kögel-Knabner, I., 2004. Alkyl C and hydrophobicity in B and C horizons of an acid forest soil. Journal of Plant Nutrition and Soil Science 167, 685-693.

Salminen, J.P., Roslin, T., Karonen, M., Sinkkonen, J., Pihlaja, K., Pulkkinen, P., 2004. Seasonal variation in the content of hydrolyzable tannins, flavonoid glycosides and proanthocyanidins in oak leaves. Journal of Chemical Ecology 30, 1693-1711.

Scott, D.F., 2000. Soil wettability in forested catchments in South Africa; as measured by different methods and as affected by vegetation cover and soil characteristics. Journal of Hydrology 231-232, 87-104.
Soil Survey Staff, 1998. Keys to Soil Taxonomy, Eight ed. USDA-NRCS, Washington DC 326. reseder, K.K., Allen, M.F., 2000. Mycorrhizal fungi have a potential role in soil carbon storage under elevated $\mathrm{CO}_{2}$ and nitrogen deposition. New Phytol. special issue: root dynamics and global change: an ecosystem perspective. 147, 189-200.

Treseder, K.K., Turner, K.M., 2007. Glomalin in ecosystems. Soil Science Society of America Journal 71, 1257-1266.

Van Bergen, P.F., Bull, I.D., Poulton, P.R., Evershed, R.P., 1997. Organic geochemical studies of soils from the Rothamsted classical experiments. I. Total lipid extracts, solvent insoluble residues and humic acids from Broadbalk Wilderness. Organic Geochemistry 26, 117-135.

Van den Bossche, H., 1990. Importance of sterols in fungal membranes. In: Kuhn, P.J., Trinci, A.P.J., Goosey, M.W., Copping, L.G. (Eds.), Biochemistry of Cell Walls and Membranes in Fungi. Springer-Verlag, Berlin, pp. 135-157.

Verheijen, F.G.A., Cammeraat, L.H., 2007. The association between three dominant shrub species and water repellent soils along a range of soil moisture contents in semi-arid Spain. Hydrological Processes 21, 2310-2316.

Walkley, A., Black, I.A., 1934. An examination of the Degtjareff method for determining soil O.M. and a proposed modification of the chromic acid titration method. Soil Science 37, 29-38.

Wallis, M.G., Horne, D.J., 1992. Soil water repellency. Advances in Soil Science 20, 91-146.

Wallis, M.G., Horne, D.J., Palmer, A.S., 1993. Water repellency in a New Zealand development sequence of yellow brown sands. Australian Journal of Soil Research 31, 641-654.

Wessel, A.T., 1988. On using the effective contact angle and the water drop penetration time for classification of water repellency in dune soils. Earth Surface Processes and Landforms 13, 555-562.

White, N.A., Hallett, P.D., Feeney, D., Palfreyman, J.W., Ritz, K., 2000. Changes to water repellence of soil caused by the growth of white-rot fungi: studies using a novel microcosm system. FEMS Microbiology Letters 184, 73-77.

Wright, S.F., Upadhyaya, A., 1996. Extraction of an abundant and unusual protein from soil and comparison with hyphal protein from arbuscular mycorrhizal fungi. Soil Science $161,575-586$.

Young, I.M., Feeney, D.S., O'Donnell, A.G., Goulding, K.W.T., 2012. Fungi in century old managed soils could hold key to the development of soil water repellency. Soil Biology and Biochemistry 45, 125-127.

Zavala, L.M., González, F.A., Jordán, A., 2009. Intensity and persistence of water repellency in relation to vegetation types and soil parameters in Mediterranean SW Spain. Geoderma 152, 361-374. 